\title{
Sudden death from rupture of cerebral abscess into subarachnoid space
}

\author{
Courtney Curran, ${ }^{1}$ Ambica Nakhasi, ${ }^{2}$ Gina Prochilo, ${ }^{3}$ Tapan Kavi ${ }^{4}$
}

${ }^{1}$ Cooper Medical School of Rowan University, Camden, New Jersey, USA

${ }^{2}$ Department of Neurology, Cooper University Hospital, Camden, New Jersey, USA ${ }^{3}$ Department of Pathology, Robert Wood Johnson University Hospital, New Brunswick, New Jersey, USA

${ }^{4}$ Department of Neurology and Neurosurgery, Cooper University Hospital, Camden, New Jersey, USA

\section{Correspondence to Courtney Curran,}

curranc2@rowan.edu

Accepted 10 November 2018

\section{DESCRIPTION}

A Mexican man in his mid-30s with a medical history of atrial septal defect presented with sudden onset of left lower extremity weakness and a 2-week history of fever, headache and purulent rhinorrhoea. On examination, he was alert, had no cranial nerve deficits and had full strength except for mild weakness in his left lower extremity. CT head showed two right frontal hypodense lesions with surrounding oedema, mass effect and subfalcine herniation (figure 1A). Given probable recent sinusitis and the radiological features described above, the cerebral abscess was considered as the most likely diagnosis.

He was started on vancomycin, cefepime, amphotericin B, mycobacterium RIPE therapy and dexamethasone. However, the next day, he suddenly deteriorated losing all cortical and brainstem function. He was started on hypertonic saline and measures for intracranial pressure control without improvement. Emergent MRI showed ring enhancement of the previously identified lesions but no new herniation (figure $1 \mathrm{~B}$ and $\mathrm{C}$ ). He had no improvement in the examination, and the next day, a nuclear medicine cerebral flow study revealed the absence of all perfusion. He was ultimately pronounced brain dead.

An autopsy confirmed the presence of two frontal abscesses, with the most anterior extending to the superficial surface of the frontal lobe (figure 1D). Microscopy revealed bacterial abscess with gram-positive cocci in clusters and gram-negative rods. Abscess exudate was found in the subarachnoid space resulting in meningeal inflammation (figure $1 \mathrm{E}$ and $\mathrm{F}$ ). Given no significant worsening of mass effect, herniation or evidence of rupture of abscess into intraventricular space, rupture of abscess into subarachnoid space was considered the cause of sudden deterioration and brain death.

Although rare, this complication has been described before. ${ }^{1}$ The source of abscess, in this case, was likely local spread of a sinus infection, but the presence of
D Check for updates

(C) BMJ Publishing Group Limited 2018. No commercial re-use. See rights and permissions. Published by BMJ.

To cite: Curran $C$, Nakhasi $A$, Prochilo G, et al. BMJ Case Rep 2018;11:e226743. doi:10.1136/bcr-2018226743

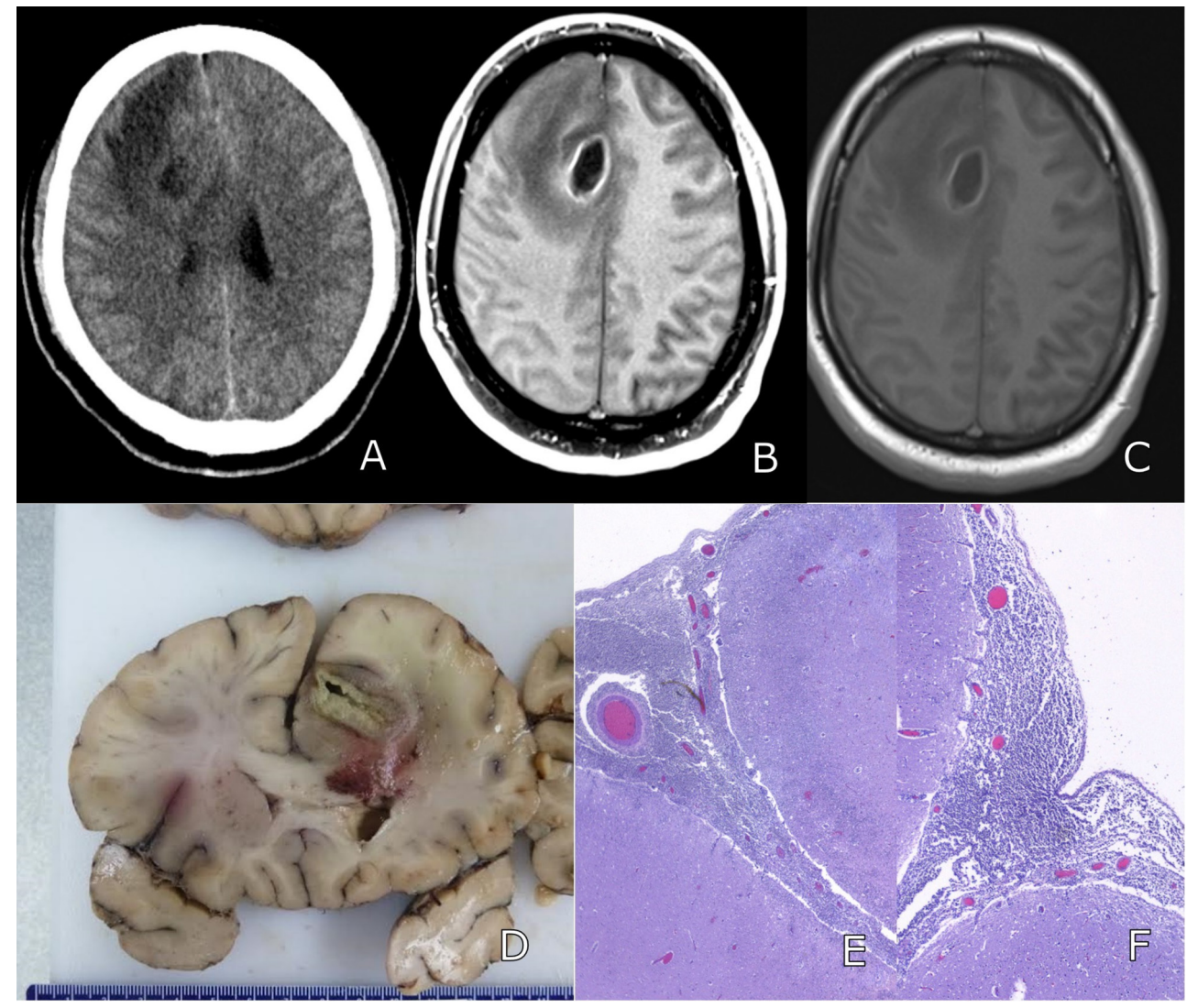

Figure $1 \mathrm{CT}(\mathrm{A})$ and MRI brain (B and $C$ ) showing right frontal hypodense lesion with surrounding oedema, mass effect and ring enhancement with gadolinium. Gross section of brain showing right frontal abscesses (D). Histological slide with H\&E stain showing left frontal $(E)$ and left occipital $(F)$ exudate from abscess rupture and meningeal inflammation. 
an atrial septal defect also predisposed him to paradoxical embolism and cerebral abscess. ${ }^{2}$ He was HIV negative and not otherwise immunosuppressed. Little is known about what increases the risk for rupture into the subarachnoid space, but multiloculation and close proximity to the ventricles increase the risk for intraventricular rupture. ${ }^{3}$ It is important to be aware of this complication, as it underlines the importance of early medical and surgical management of cerebral abscess. Further research should be done to see if these factors influence the risk of rupture into the subarachnoid

\section{Learning points}

Prompt recognition and treatment of cerebral abscess is crucial in preventing devastating complications.

- Rupture of abscess into subarachnoid space should be recognised as a possible mechanism for sudden deterioration in the absence of other complications such as intraventricular rupture and hydrocephalus, intracranial pressure crisis or seizures. space and to determine what patients are at risk for this catastrophic complication.

Contributors CC: drafted and revised the manuscript. AN: revised the manuscript. GP: analysed and interpreted data. TK: interpreted data and drafted and revised the manuscript.

Funding The authors have not declared a specific grant for this research from any funding agency in the public, commercial or not-for-profit sectors.

Competing interests None declared.

Patient consent Not required.

Provenance and peer review Not commissioned; externally peer reviewed.

\section{REFERENCES}

1 Chawla J, Husain M, Vatsal DK, et al. MR demonstration of brain abscess rupture into the subarachnoid space and its possible implication in management. Surg Neurol 2003;59:197-9.

2 Sung $\mathrm{CW}$, Jung J-H, Lee $\mathrm{S}-\mathrm{H}$, et al. Brain abscess in an adult with atrial septal defect. Clin Cardiol 2010;58:n/a-E3.

3 Lee TH, Chang WN, Su TM, et al. Clinical features and predictive factors of intraventricular rupture in patients who have bacterial brain abscesses. J Neurol Neurosurg Psychiatry 2007:78:303-9.

Copyright 2018 BMJ Publishing Group. All rights reserved. For permission to reuse any of this content visit https://www.bmj.com/company/products-services/rights-and-licensing/permissions/

BMJ Case Report Fellows may re-use this article for personal use and teaching without any further permission.

Become a Fellow of BMJ Case Reports today and you can:

- Submit as many cases as you like

- Enjoy fast sympathetic peer review and rapid publication of accepted articles

- Access all the published articles

- Re-use any of the published material for personal use and teaching without further permission

For information on Institutional Fellowships contact consortiasales@bmjgroup.com

Visit casereports.bmj.com for more articles like this and to become a Fellow 